\title{
FUTURE DEVELOPMENT OF COMMON AGRICULTURE POLICY AFTER 2020
}

\author{
D. Ivanov* \\ European Parliament, Brussels, Belgium
}

\begin{abstract}
The object of this scientific paper is analysing the most recent developments and the future impact of CAP after 2020. The paper aims to present and analyze the results and perspectives of the current EU policy for agricultural sector, possibilities to increase its efficiency and also to make proposals and conclusions in order to optimize the effect of CAP for the EU farmers and consumers. The methods used for the paper are examination of the latest reports, proposals and statistical data, research and analysis of literature, observation and expert evaluation.
\end{abstract}

Key words: CAP 2020, results, developments, perspectives

\section{INTRODUCTION}

\section{The Common Agricultural Policy of} the $\mathrm{EU}$ - a retrospective view

The Common Agricultural Policy (CAP) is one of the first (founded in 1962) and the most important European policies set up to ensure a sustainable supply of affordable food for European citizens and to guarantee an acceptable standard of living for EU farmers . Why is the CAP one the first Community policy? The six founding countries of the European Communities (with the 1957 Treaty of Rome) are vowed to never allow the hunger and dearth of post-war Europe. In the 1950s, the lack of basic food products was a mass phenomenon, and even a Western-style coupon system for some products was introduced in Western Europe. In the abundance of foods we have today, this may sound distant and odd, but unfortunately it was a reality for our ancestors.

In the same way that we say that a country's defense capabilities and energy security are strategic sectors, this is even more relevant to our food security.

The policy should help to increase agricultural productivity, stable prices and a dignified life for farmers. To reassure producers that there is no risk to them, the Community promises to buy back the surpluses that farmers have failed

\footnotetext{
*Correspondence to: Dimo Ivanov, European

Parliament, Brussels, Belgium, e-mail:

dimo.ivanov@europarl.europa.eu
}

to sell. Special charges are levied on imported goods to ensure that local produce is more profitable. Exports of products to nonCommunity markets receive subsidies. Farmers are starting to produce more than needed. As a result, "mountains" of butter, cereals and beef, "lakes" of wine and milk are being grown in the seventies and eighties.

In order to balance the huge surpluses of output with the real needs of the market, the CAP is going through its first reform in the early 1990s (MacSharry reform 1992), which aims to eliminate the link between subsidies and production. Production support goes to support directly for the farmer (direct income support to farmers).

With every subsequent reform, Plan 2000, Fisher (2003), Health Check 2008, the 2013 reform, the CAP is becoming more marketoriented and competitive while integrating the social and environmental dimensions (viable rural areas, climate change, quality Food, animal welfare, etc.).

The CAP sets out three long-term priorities for rural development in the 2014-2020 period:

$\checkmark$ Economic (viable food production, enhancing competitiveness and improving the organization of the food chain);

$\checkmark$ Ecological (sustainable management of natural resources and combating climate change);

$\checkmark$ Territorial (balanced rural development across the EU). 
The most significant change introduced by the 2013 reform is linked to the introduction of the green component in the first pillar (so-called "green measures") and the second pillar (agrienvironment payments) of the CAP. The 20142020 CAP budget provides over $€ 100$ billion of investment to ensure soil and water quality, biodiversity conservation and climate change.

For 1st pillar - direct payments - 30\% of national direct payment packages must be linked to the implementation of environmentally sound practices (diversification of crops, maintenance of permanent pasture, etc.).

Under the second pillar (rural development), voluntary measures are introduced - at least $30 \%$ of the budget of rural development programs should be earmarked for agrienvironmental measures, support for organic farming, areas with natural constraints or part of Natura 2000. For forestry activities or for projects related to innovative investments or measures for the benefit of the environment.

2. In depth analysis of the EU agricultural sector and the Future of CAP after 2020

2.1. The importance of the agricultural sector for the European economy

The agricultural sector is structurally relevant to the EU, not only because of the food security of nearly 500 million consumers. Agriculture and the food industry, which is heavily dependent on it for its supplies, together account for $6 \%$ of EU GDP, 15 million enterprises and nearly 46 million jobs 22 million in agriculture, over 4 million jobs in the processing sector and more than 17 million in the service and retail sector.

The EU is a net exporter of food and agricultural products - the EU confirms its global position as an exporter of agricultural food products. Exports of agricultural food products reached $€ 129$ billion in 2015 , Over $7 \%$ of all goods exported by the EU. In addition to feed and food of agricultural origin, for example, wines, cereals, meat, olive oil, dairy products are exported.

More than $77 \%$ or $3 / 4$ of EU territory are rural areas $(47 \%$ of agricultural land and $30 \%$ of forests), inhabited by about half of its population (agricultural communities and other inhabitants).

\subsection{Next reform of the CAP?}

The EU has already begun the debate on the vision of the CAP after 2020. $\checkmark$ The Cork Declaration - "Cork 2.0" ("Better living in rural areas") - In September 2016, the European Conference on Rural Development in Cork, Ireland, with the participation of European Commissioner for Agriculture Phil Hogan, discussed the guidelines for the future of agriculture;

$\checkmark$ Report of the EC Agricultural Market Expert Group - this is a kind of "think-tank" of the European Commission and the recommendations in this report will be taken into account in the reform of the CAP;

$\checkmark$ Mid-term review of the Multiannual Financial Framework, Omnibus - besides the financial parameters, the proposal discusses options for simplifying the CAP and its implementation;

$\checkmark$ Public Discussion on the Future of the CAP - In early February this year the EC launched a public consultation to modernize and simplify the CAP. Discussion is an online questionnaire that can be completed by May 2. The results of the consultation will be summarized and published on the Commission's website in July 2017.

It is a fact that negotiations on the future CAP are taking place in a very different international environment. Speaking of the challenges ahead, we can not overlook the new economic, social and environmental realities, such as:

$\checkmark$ Political challenges related to migration, the rise of terrorist groups, the geopolitical threats, the new political situation in United States, Brexit, etc.;

$\checkmark$ Economic and social attitudes related to the funding of politics and threats to democracy, with the rise of populist movements in many European countries;

$\checkmark$ The environmental dimension of climate change and new consumer attitudes (increasing interest in clean food and production methods, animal welfare and changing attitudes to meat consumption).

In the following chapters we shall analyze and examine the different aspects of the vision of CAP, namely- its financing, the food dimension, climate change, young farmers and innovation in agriculture.

\subsection{CAP funding in figures, future of Direct payments}

CAP funding should focus on the achievement of specific objectives by each group of farmers (support to be tailored to local peculiarities):

$\checkmark$ Investments in development and innovation in agriculture for large farmers; 
$\checkmark$ Expanding production and investment in technology for medium-sized holdings;

$\checkmark$ Social measures for small farmers.

Direct payments have been created as an instrument to cope with market turbulence (with a sharp drop in producer prices and hence farmers' incomes), but they are not actually used as a crisis response tool. Take the example of the dairy crisis where, despite direct payments for milk producers, the EC has adopted extraordinary measures in the form of bailouts (EUR 1 billion).

Direct payments also have a negative effect on the price of agricultural land - the price is raised artificially, making it unavailable to farmers. On the other hand, direct payments also have a negative impact on the conditions for granting credit. Increasingly, credit institutions report direct payments that a farmer receives as credit terms.

Support to be linked to the achievement of specific objectives rather than the assets owned, as is the case - direct payments follow the owner of the assets (the landowner) rather than the real operator / farmer (active farmer). A clear distinction should be made between the owner of the assets and the operator.

In view of the shortcomings of the current system of direct payments, the possibility of their gradual suspension (a 15 year transition) is being discussed and a new approach is proposed where funds are directed to risk management tools in agriculture (in the form of a bonus / valuable book).

Farmers are becoming more and more dependent on direct payments, and any future change to the CAP must be phased: "With the future CAP we aim for evolution, not for revolution."

Agricultural Risk Management Tools - Need for rapid and timely response to emerging agriculture crises (example - the EU's inefficient and delayed response to the Russian embargo crisis).

Innovation instead of subsidies - new technologies will play an increasing role in agriculture and farmers will have to adapt to this new reality.

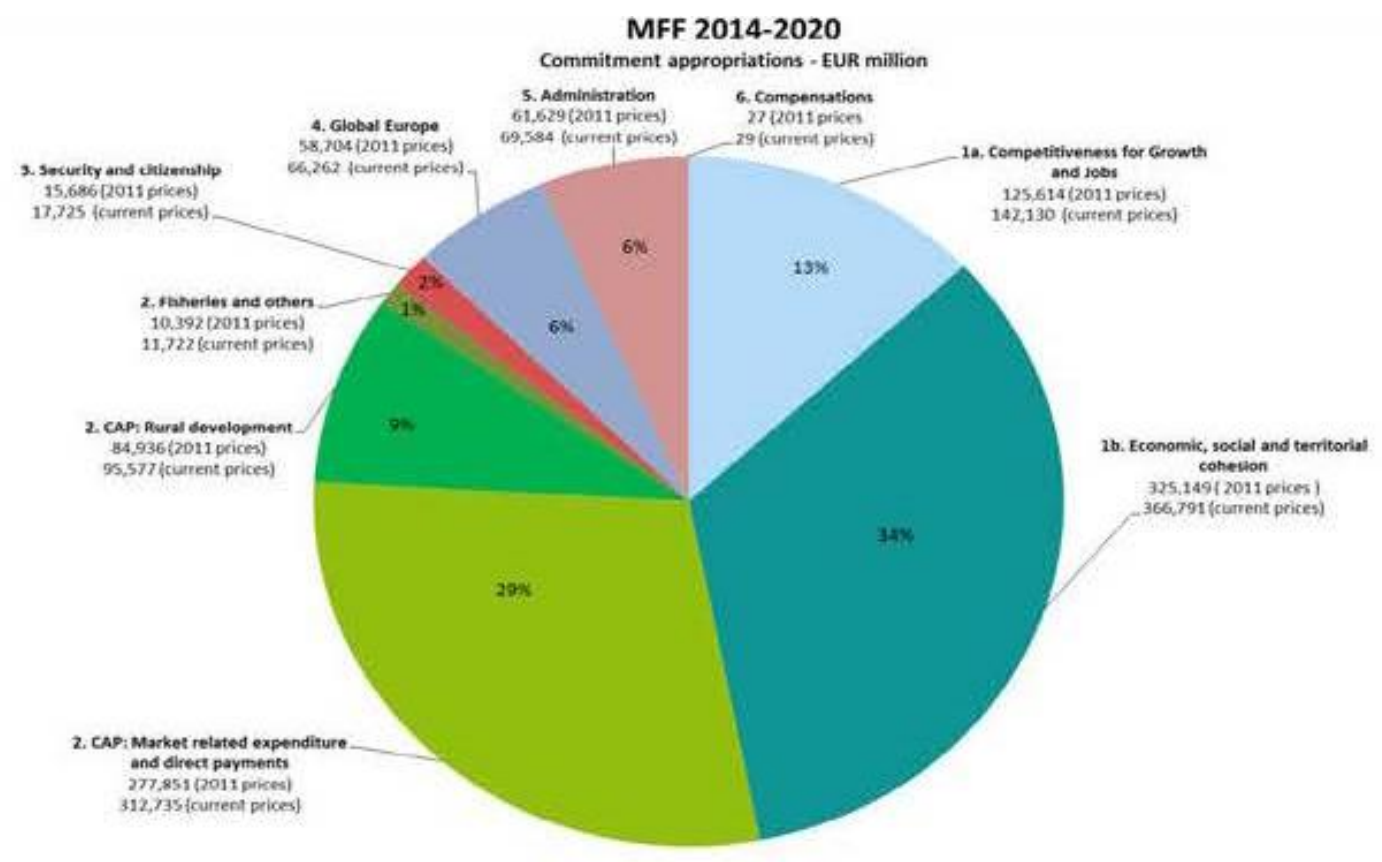

\section{Source: European Commission, DGAGRI}

Figure 1. MFF 2014-2020

\subsection{CAP and food}

In the negotiations on the future of the CAP, there is a growing debate about a distinct dimension of food-related policy.

First of all, this is due to the growing need for food production - the world population is expected to reach 9.6 billion people by 2050 . Of all human activities agriculture is most needed because no human being can live without food. On the other hand, people's attitude towards food is changing. Consumers are increasingly concerned about product 
quality and production processes and are looking for healthy food.

The main questions are related to food quality ("What I consume, good for my health?"), Transparency ("Do I know what's on my plate?") And sustainability ("When I buy your product, Model I believe in?"). All this determines the growing demand for locally produced food, which is clean and organic. This reduces the supply chain (direct produceruser relationship) and reduces the carbon footprint on the environment (food is not delivered at thousands of kilometers away).

In order to protect farmers and to obtain fair compensation for production and the effort made, we have to fight at the European level with unfair commercial practices in the food supply chain. Farmers are at the heart of the food supply chain and are the most vulnerable when negotiating purchasing and selling conditions with other stakeholders. That is why one of the principles is to establish fair and transparent contractual relations between producers, retailers and the shop network.

On the other hand, the role of producer organizations, which can help to strengthen farmers' positions when negotiating with other actors in the food chain, is also important, through the possibility of collective bargaining and supply contracts. This will reduce the risk of price dumping for farmers' products (e.g. the price of milk).

Speaking of food quality, the EU produces some of the best quality products that are sought after all over the world. European quality schemes, through trademarks of geographical indications and protected designations, contribute to the unique taste and quality of European products. This creates identity and is a strong stimulus for the development of small communities.

\subsection{CAP and the environment}

Increased pressures on natural resources, due to increasing food, feed, cellulose and biomaterial needs, should be reduced. Sustainable land, soil and water management is needed to preserve biodiversity. It is necessary to apply more agri-environmental practices in agriculture.

Agriculture is one of the sectors that emit the most greenhouse gas emissions. We need not only an economy but an economy based on the principles of clean and sustainable agriculture. Developing the Circular Economy and Enhancing the Bio-Economy - a Role of Forests.

\subsection{CAP and young people}

Rural areas face serious challenges related to the depopulation and outflow of young people, as well as an aging population in the agricultural sector. Almost 30\% of farmers in the EU-28 are retired (over 65), with about $53 \%$ aged $55+$. Only $7.5 \%$ of all farmers are under 35 . The need for generational change is obvious, but how can this process be stimulated and stop young people from falling into the big cities?

Every young person's aspirations for education, professional and personal realization, a good social environment, and a well-paid job are natural. The EU is working hard on the concept of so-called "Smart village" - smart village, i.e. a village where digital connectivity and social infrastructure go hand in hand to create the right conditions for new jobs and a desire for village life. But we must not forget the city-village connection and the opportunities that exist in urban and peripheral areas for the development of urban and peri-urban agriculture.

At the same time, the question of access to arable land and bank credit is the biggest challenge for the young person who wants to be engaged in agriculture. Agricultural land prices are rising steadily, which prevents startup farmers from buying even a few acres. On the other hand, banks are reluctant to grant loans to young farmers to purchase land because of the high risk of farming and the lack of credit history.

One of the most recent report of the European parliament aims to protect the European model of agriculture characterized by small and family farms as well as measures against land concentration in the hands of investors outside the agricultural sector. And on financing, in cooperation with the European Investment Bank, new financial instruments are being prepared to make it easier for young farmers to access financial resources (by providing bank guarantees and better credit conditions).

Speaking of you young people, there is no way to overlook the theme of innovation. As part of the digital generation, they are the natural bearer of this change. More and more resources will be earmarked for the development of the so-called Smart farming or precision farming using new technologies to produce more in a sustainable way by preserving natural resources. For example, by producing a digital map of the arable field that gives accurate soil, climate, plant state indications, it will be possible to reduce the 
amount of fertilizers and pesticides applied. Research innovations also allow for the development of organic fertilizers and plant protection that conserve plants and are also used in organic farming.

The goal of precision farming is to meet the demographic challenges of a growing population - according to the Food and Agriculture Organization of the United Nations, by 2050 , the world's population will reach 9.6 billion people, which will increase the need for food production by $70 \%$.

Social Entrepreneurship - Innovation is not just new technology, but new organizational processes and social practices. Innovative activities can be developed in traditional rural sectors.

\section{CONCLUSIONS}

For the future development and efficiency of the EU agricultural sector, it is crucial to respond to all the practical questions posed before the next 2020- programming period due to the need to modify the conditions for application and to achieve effective and efficient outcomes. CAP has a leading role and major impact on the sector, on supporting the farms and their sustainability, the consumer protection, social and climate dimensions of the rural areas, but its importance could be more effective if the existing problems are overcome.

\section{REFERENCES}

1. DG AGRICULTURE, European Commission

2. EUROSTAT

3. http://www.forumforagriculture.com/cometo-ffa/

4. http://enrd.ec.europa.eu/sites/enrd/files/cork -declaration_en.pdf

5. http://www.europarl.europa.eu/RegData/etu des/STUD/2016/585898/IPOL_STU(2016) 585898(SUM01)_BG.pdf

6. https://ec.europa.eu/agriculture/agrimarkets-task-force_en 